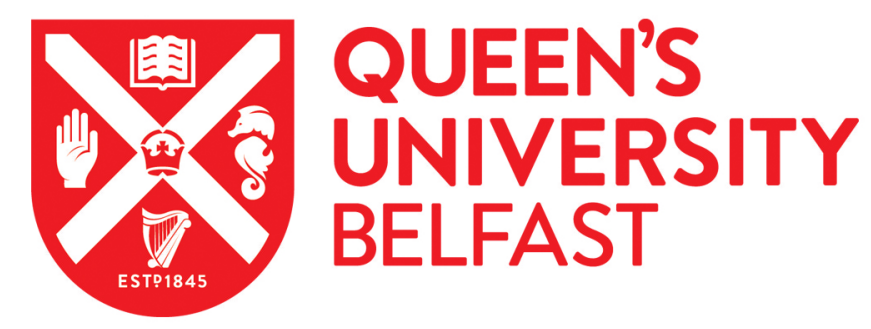

\title{
Rapid construction of arch bridges using the innovative FlexiArch
}

Long, A., Kirkpatrick, J., Gupta, A., Nanukuttan, S., \& McPolin, D. (2013). Rapid construction of arch bridges using the innovative FlexiArch. Proceedings of the ICE - Bridge Engineering, 166(3), 143-153.

https://doi.org/10.1680/bren.11.00036

\section{Published in:}

Proceedings of the ICE - Bridge Engineering

\section{Document Version:}

Publisher's PDF, also known as Version of record

\section{Queen's University Belfast - Research Portal:}

Link to publication record in Queen's University Belfast Research Portal

\section{Publisher rights}

(c) 2013 ICE

Permission is granted by ICE Publishing to print one copy for personal use. Any other use of these PDF files is subject to reprint fees

\section{General rights}

Copyright for the publications made accessible via the Queen's University Belfast Research Portal is retained by the author(s) and / or other copyright owners and it is a condition of accessing these publications that users recognise and abide by the legal requirements associated with these rights.

Take down policy

The Research Portal is Queen's institutional repository that provides access to Queen's research output. Every effort has been made to ensure that content in the Research Portal does not infringe any person's rights, or applicable UK laws. If you discover content in the Research Portal that you believe breaches copyright or violates any law, please contact openaccess@qub.ac.uk. 


\section{Rapid construction of arch bridges using the innovative FlexiArch}

1 Adrian Long OBE, FREng, PhD, DSC, FICE, FIStructE Queen's University Belfast, Belfast, UK

2 Jim Kirkpatrick BSC, PhD, CEng, FIStuctE, FIEI Macrete Ireland Ltd, Toomebridge, UK

3 Abhey Gupta BTech, MTech, MPhil Macrete Ireland Ltd, Toomebridge, UK
4 Sreejith Nanukuttan PhD Queen's University Belfast, Belfast, UK

5 Daniel Mc Polin BEng, MSc, PhD Queen's University Belfast, Belfast, UK
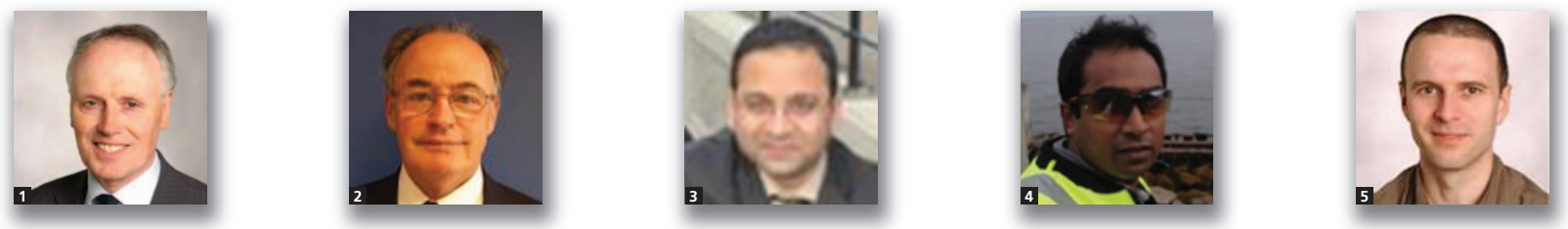

Masonry arches are strong, durable, aesthetically pleasing and largely maintenance free, yet since 1900 there has been a dramatic decline in their use. However, designers, contractors and clients now have access to a new method of constructing arches incorporating precast concrete voussoirs interconnected via polymeric reinforcement and a concrete screed. No centring is necessary, as the FlexiArch, when it is lifted, transforms under the forces of gravity into the desired arch shape. After discussing general aspects of innovation, the basic concept of the arch bridge system is presented along with technological advances since it was patented. Experiences gained from building over 40 FlexiArch bridges in the UK and Ireland and from model and full-scale tests carried out to validate the system during installation and in service are described. Thus under load the system behaves like a traditional masonry arch and existing analysis methods can be used for design and assessment.

Notation
$b$
$d$
$T$
$W$

width of voussoir at the top depth

force in the polymeric reinforcement weight of an individual voussoir

\section{Introduction}

One of the most important innovations that has impacted greatly on mankind is the wheel. The earliest form was probably inspired by nature, as was the arch. Both have been in existence for thousands of years and have contributed greatly to the development of our infrastructure and society.

Currently there are some 70000 masonry arch bridges in the UK, some showing signs of deterioration, but in general they have stood the test of time much better than other more recent forms of construction. For example beam and slab bridges built in the 1960s and 1970s, even though they had design lives of 120 years, have shown signs of deterioration after only 20-30 years and indeed many have already had to be replaced.
In contrast a significant number of masonry arch bridges are still in service some 2000 years after being constructed. This prompts us to ask the question, why is it that bridge engineers in the UK, and in many other countries, seldom use arch bridges? Currently the majority of recent short-span bridges are of beam and slab construction, yet arches are aesthetically pleasing, strong, and durable and require little maintenance. These qualities have been recognised by the UK Highways Agency (2004), which recommends the use of the arch form where ground conditions permit and also states that 'consideration shall be given to all means of reducing or eliminating the use of corrodible reinforcement'.

Could it be that speed of construction, arising from the use of precast prestressed concrete/steel beams has placed conventional masonry arch construction at a severe disadvantage? This has resulted in arches not being specified or built except for specific projects where aesthetics are of paramount importance. In such instances many recently constructed 'arch' bridges have been rigid precast concrete arches with high levels of reinforcement so that they could be safely lifted into position. Apart from being difficult to precast, store and 
transport to site, such arches will be subject to corrosion/ durability related damage, such as beam and slab bridges, and will not have the high levels of durability enjoyed by unreinforced masonry arches.

Thus the innovation challenge is to produce an arch system that has all the attributes of a masonry arch but also

(a) can be constructed/installed as quickly as alternative types of bridges

(b) does not require centring, which is expensive to construct and can be difficult to remove

(c) is cost competitive

(d) uses high-quality precast concrete for the construction of the voussoirs, thus avoiding the costly and time-consuming production of accurate stone voussoirs

(e) lends itself to design/build and offsite construction

Innovative thinking was necessary to meet these and other challenges and details of the approaches utilised will be discussed. However, before this, some general information will be provided on how innovation can be nurtured.

\section{Innovation - innovative engineering}

It has been recognised by governments all over the world that companies with an emphasis on innovation are generally among the most profitable. Thus innovation has been one of the key issues that British companies have been urged to address to help them compete on international markets. Much has been written about this important topic, mainly in management journals with limited links to technological innovation. However, useful guidance on the nurturing of innovation is given in a relatively recent paper.

In the IMechE 2002 James Clayton Memorial Lecture, Howells (2002) addressed the topic 'Innovation that delivers profitable growth' and some aspects which he considered to be most relevant will be highlighted. Howells was employed for 28 years by 3M (Minnesota, Mining and Manufacturing Co), one of the most innovative companies in the world. Their vision for 'Innovation technology for a changing world' owes much to the policies, practices and philosophies of William McKnight who was Chairman from 1949 to 1966.

McKnight (Howells, 2002) accepted that

mistakes will be made, but if a person is essentially right, the mistakes he or she makes are not as serious, in the long run, as the mistakes management will make if it is dictatorial and tells those under its authority exactly how they must do their job.

Management that is destructively critical when mistakes are made kills initiative. And it's essential that we have people with initiative if we are to continue to grow.
He allowed staff to spend $15 \%$ of their time on their own ideas as 'the first principle is the promotion of entrepreneurship and the insistence upon freedom in the workplace to pursue innovative ideas... ...put fences around people and you get sheep'.

On the basis of his wide experience of working with $3 \mathrm{M}$ he concluded that 'technical personnel who understood the technology and were in close contact with customer applications were the main catalysts to deliver the innovation'.

More generally Howells came to the conclusion that, in order to deliver innovation, you need
abborn persistence, courage, curiosity and patience
creative use of failure - revisiting old ideas
- supportive and hands-on management
- individuals with initiative (product champions) together with cross-functional teams

Experience gained from the development of the FlexiArch has allowed the authors to assess the validity of these key points in relation to the system innovation, which will now be described.

\section{Innovative concept and method of manufacture}

Overcoming the challenges identified in the introduction could unlock the full potential of the arch and this would be welcomed by practising engineers aware of the merits of the arch system. However, a completely new approach to the construction of arches, as is outlined below, would be necessary.

The system is constructed and transported in the form of a flat pack using polymeric reinforcement to carry the self-weight during lifting but behaves as a masonry arch once in place. The preferred method of construction is as shown in Figure 1 where the tapered voussoirs are pre-cast individually and then laid contiguously in a horizontal line with a layer of polymeric reinforcement placed on top. An in situ layer of concrete, approximately $40 \mathrm{~mm}$ thick, is then placed on top and allowed to harden to interconnect the voussoirs.

Here it should be noted that changing the taper of the voussoirs allows the production of arches with different radii of curvature. For example low rise to span segmental circular arches require little taper. In addition, as the system is assembled on a flat surface, the FlexiArch units can be stacked for storage and transportation to site in flat pack form.

An alternative monolithic form of construction, involving the use of precision wedges in complex/expensive formwork, was 


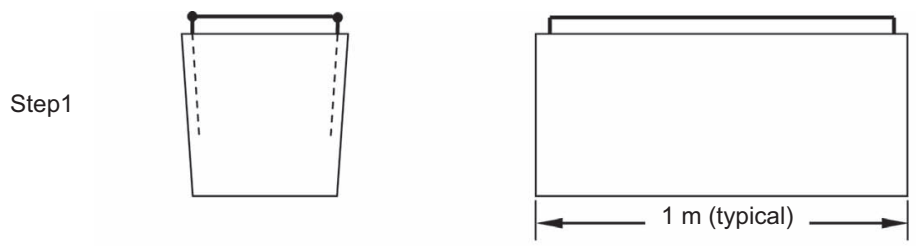

Voussoirs individually precast in accurately manufactured moulds. Minimal shuttering requirements as all the voussoirs are identical for a circular arch

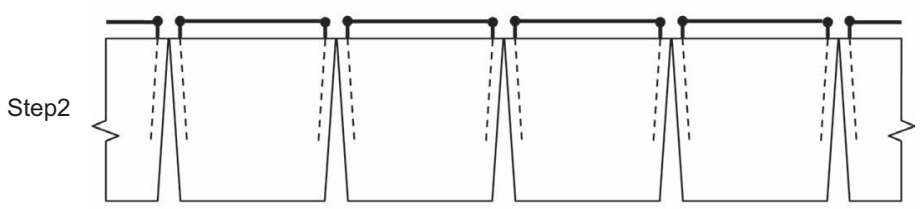

Voussoirs placed in a horizontal line with top edges touching

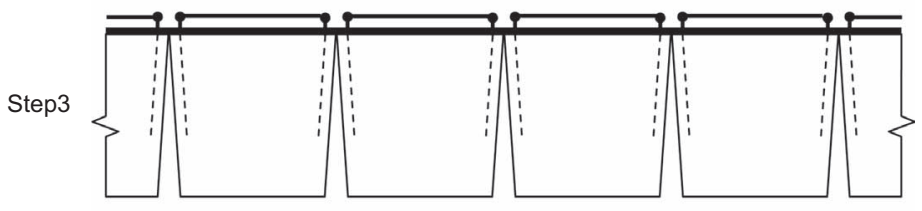

Polymeric reinforcement stretched along (in contact with) top of voussoirs

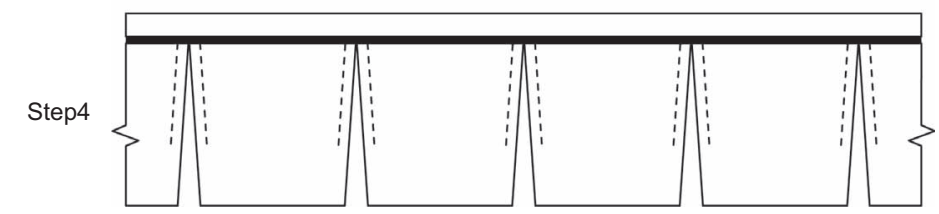

In situ screeding layer is placed on top and allowed to harden to interconnect the voussoirs and produce a FlexiArch unit ready for lifting

Figure 1. FlexiArch method of construction

not considered to be practicable and experience has shown that the above method (Figure 1) has the following advantages

the voussoirs can be accurately and consistently produced with the desired taper in relatively inexpensive shuttering

- high-quality concrete can be used for the individual precast voussoirs to enhance the durability of the arch unit once in place

- the polymeric reinforcement can be accurately located as it lies on top of the hardened concrete in the voussoirs.

The arch unit can be cast in convenient widths, usually $1 \mathrm{~m}$, to suit the design requirements, site restrictions and available lifting capacity. When lifted gravity causes the wedge-shaped gaps to close, concrete hinges form in the top layer of concrete and the integrity of the unit is provided by tension in the polymeric reinforcement and the shear capacity of the concrete screed. The arch-shaped units are then placed on precast footings and all self-weight is then transferred from tension in the polymeric reinforcement to compression in the 'voussoir' elements of the arch; that is, it acts in the same way as a conventional masonry arch.

\section{Innovation: impact on the development of the FlexiArch}

In order to link the general views on innovative engineering with the developments of the system a brief overview of some of the milestones and influences is necessary. In the 1990s the first author was returning to Belfast with Gordon Millington after a meeting of the Structural Group Board of ICE and Gordon asked the question: 'Why is it that very few arch bridges have been built since the early 1900s as they are aesthetic, strong and durable and require little maintenance?' This perceptive question identified real problems and acted as a catalyst for the work, and over the next few years a number of research projects were targeted at the resolution of this issue. Early on it was realised that centring, with its high cost and intensive labour requirements, was a major stumbling block, as was the need for skilled bricklayers and stonemasons. However, it took until the late 1990s before the basic concept 
of the system was realised. In hindsight the previous experiences of the first author had a significant influence on the patent (Long, 2004). These included

over 30 years of research on concrete including arching action in reinforced concrete slabs

a design of concrete hinges to allow articulation in bridges, when working on bridge design in Toronto in the 1960s

understanding of the concept of aggregate interlock as a means of resisting shear (supervision of research in the 1980s (Rankin and Long, 1987))

basic understanding of geotextiles from parallel research at Queen's University Belfast in the 1980s: the flat/flexible characteristics of polymeric reinforcement are ideal for these applications with the benefit of being non-corrodible.

Transforming these ideas into a form suitable for a patent needed someone with experience of research and bridge design and fortunately the second author was able to provide this expertise with support from a Patent Agent and Queen's University. Once the patent had been filed, it was decided that close links with a precast manufacturer with relevant expertise would be essential to develop the FlexiArch system. Macrete Ireland (Toomebridge) were approached, as they had wide experience of producing precast concrete beams and arches for markets in GB and Ireland. Realising the potential of the arch bridge system, they became enthusiastic members of the team. Over the past 5-6 years enormous advances have been made, as can be seen from the rest of this paper: however, the experience gained resonates with some of the points made in the paper by Howells (2002). More specifically

- freedom to make mistakes, especially at the early stages, was essential, but lessons were learnt and a much improved end product has resulted

time is required to allow basic thinking to be done and for the various ideas being explored to gel together

- selection of a team with the requisite expertise, enthusiasm and persistence is key to overcoming the challenges encountered.

Innovation is difficult to define precisely, but from our experiences with the system it needs to be driven by personnel with relevant engineering experience who understand the technology. As with high-quality research, good management is helpful, but free time to think allied to a supportive/ facilitating environment is essential. Facilitation is a much more important key to unlocking innovative advances than intrusive management.

\section{Lifting and installation of FlexiArch units}

Basic calculations and experience of lifting $1 \mathrm{~m}$ wide FlexiArch units have indicated that for a FlexiArch with 23 voussoirs, for example, the two lifting points should be located along the centre-line of the seventh voussoir from each end. Thus when lifted, the two end sections act as cantilevers with maximum bending moments/shear forces at the interface between the sixth and seventh voussoirs. This produces a moment of $1 / 2(6 b)^{2} W$ and a shear of $6 W$ where $b=$ width of voussoir at the top and $W=$ weight of an individual voussoir ( $1 \mathrm{~m} \mathrm{long}$ ). Under these forces the concrete in the screed cracks, allowing articulation, so that the wedge shaped gaps between the voussoirs close. On the basis of the free body diagram shown in Figure 2 the moment is resisted by the force in the polymeric reinforcement $T$ multiplied by $d$ where $d$ is assumed to be the depth shown. Thus for equilibrium $1 / 2(6 b)^{2} W=T d$ and the force $T$ in the polymeric reinforcement can be found. In addition the shear is resisted by aggregate interlock within the screed (neglecting any benefit arising from friction between the voussoirs). Here it should be noted that the full depth to the bevel on the voussoir has been assumed for the lever arm, as calculations indicated that at the most the compression force $C$ would only be distributed over a depth of a few millimetres. This assumption was also used for determining the strength of the polymeric reinforcement. It is evident from the above that the integrity of the system during lifting/installation is highly dependent on the strength of the polymeric reinforcement in tension and the concrete screed in shear. As the polymeric reinforcement is normally used for geotechnical applications it was considered to be essential for it to be tested under the precise boundary conditions pertaining to the arch bridge system.

On this basis beam tests were carried out as indicated in Figure 3 with the moment to shear ratio precisely matching that occurring in the cantilever of the system. These tests were carried out at Queen's University for the size of voussoirs appropriate for a $5 \mathrm{~m}$ span $\times 2 \mathrm{~m}$ rise arch. However, when tests had to be carried out on larger voussoirs (for a $10 \mathrm{~m}$ span $\times 2 \mathrm{~m}$ rise) the beams were found to be too heavy to handle in
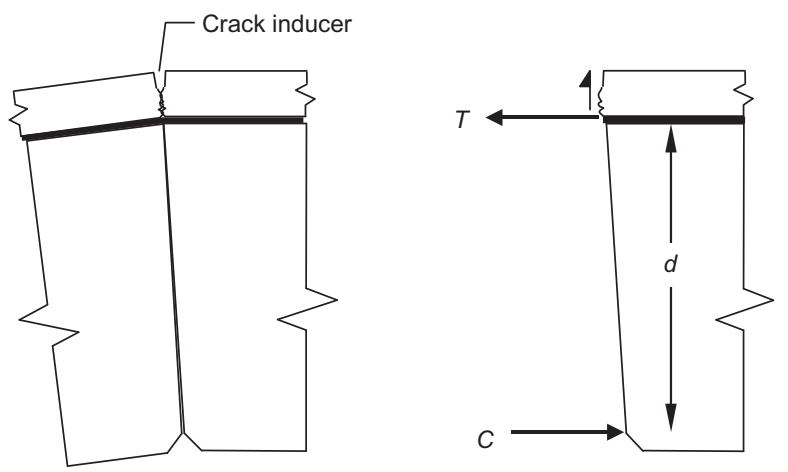

Figure 2. Forces at interface between voussoirs during lifting 
the University laboratories; thus it was decided to carry out the tests at Macrete.

After careful consideration it was decided to carry out cantilever tests on a full-length system which was subsequently lifted in sequence at each of the points indicated in Figure 4(a). This approach had the following advantages over the beam test

the test specimens did not have to be inverted prior to testing (not a simple task when the total weight is over $2 \mathrm{t}$ )

- the boundary conditions closely replicate those experienced by the cantilever sections of a FlexiArch when being installed

- loading of the polymeric reinforcement was self induced when the system was lifted using a crane (readily available at Macrete) with adequate capacity

a the system can be used for spans in excess of $10 \mathrm{~m}$.
Deflections relative to the initial sag at the lifting point were measured using a laser level system with the self-plumbing scale indicated in Figure 4(b), which also shows typical overall deformations. At high load levels there was evidence of considerable creep deformations, as had already been found from the beam tests (Figure 3 ) in the laboratory. Overall there was good agreement between the two different types of test and typical results are given in Table 1 .

Clearly the decision to test the polymeric reinforcement under conditions which replicated the installation boundary conditions in a FlexiArch was vindicated. Using these load capacities for the polymeric reinforcement and taking account of creep effects, an appropriate load factor was applied to ensure there was no risk of failure during lifting (as the force in the polymeric reinforcement in a specific FlexiArch, with defined lifting points, could be accurately predicted).

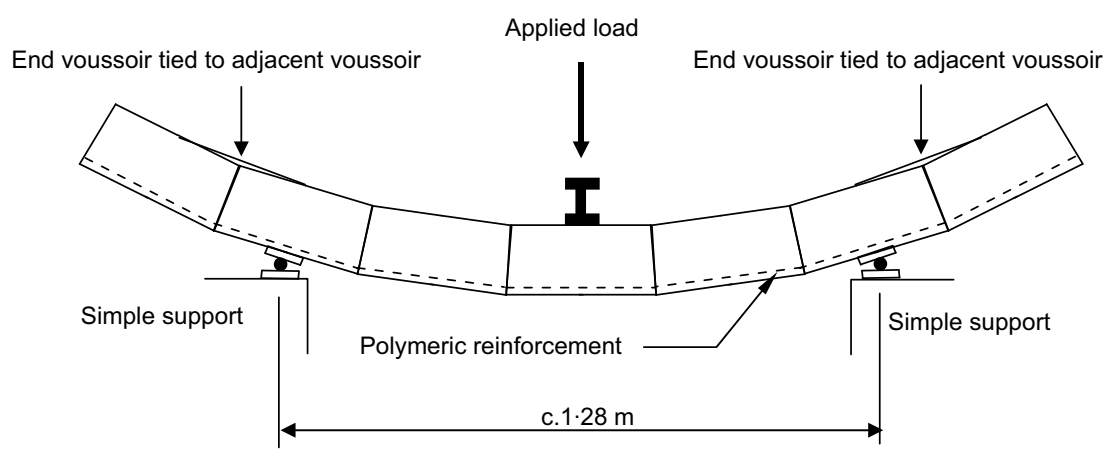

(a)

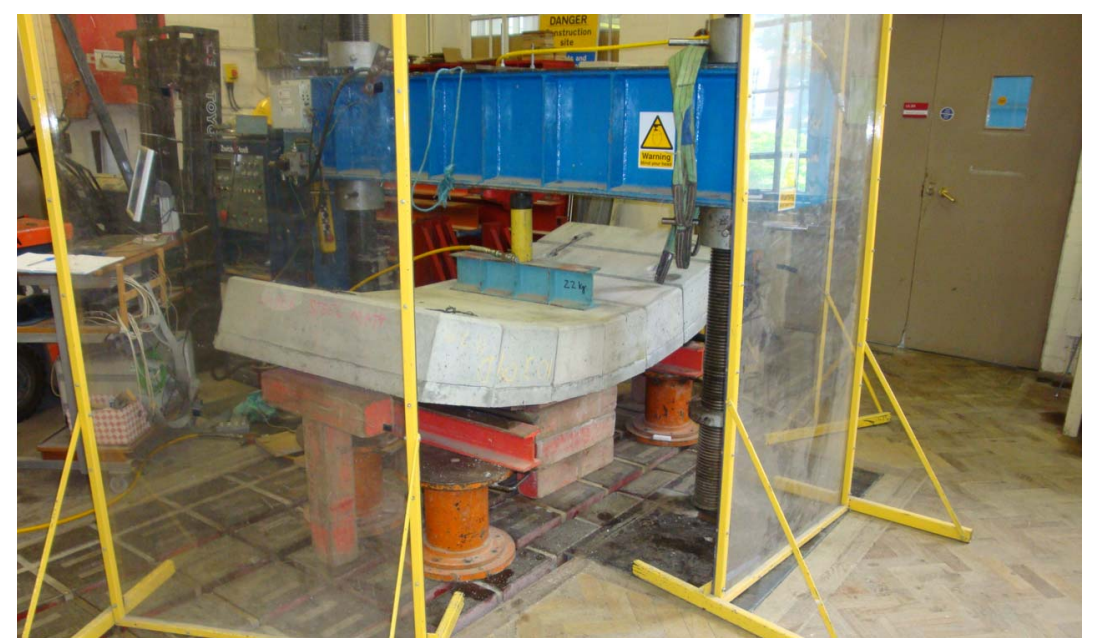

(b)

Figure 3. (a) Beam test set-up for polymeric reinforcement;

(b) beam test 


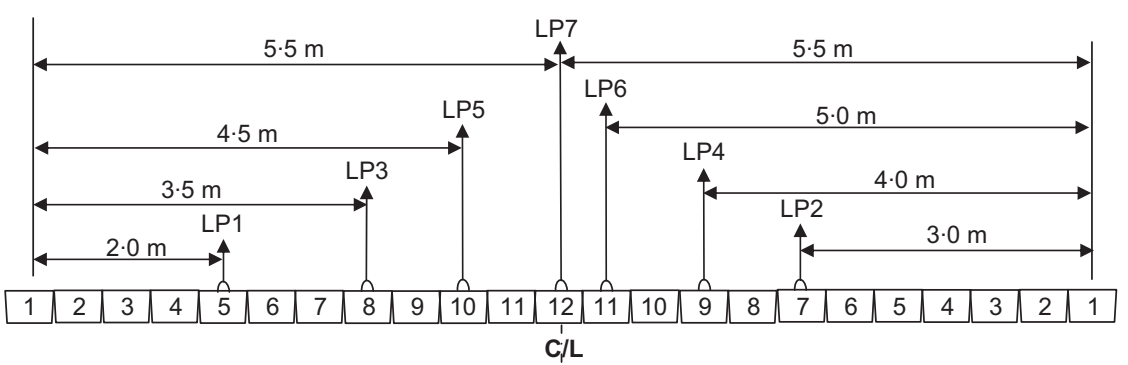

(a)

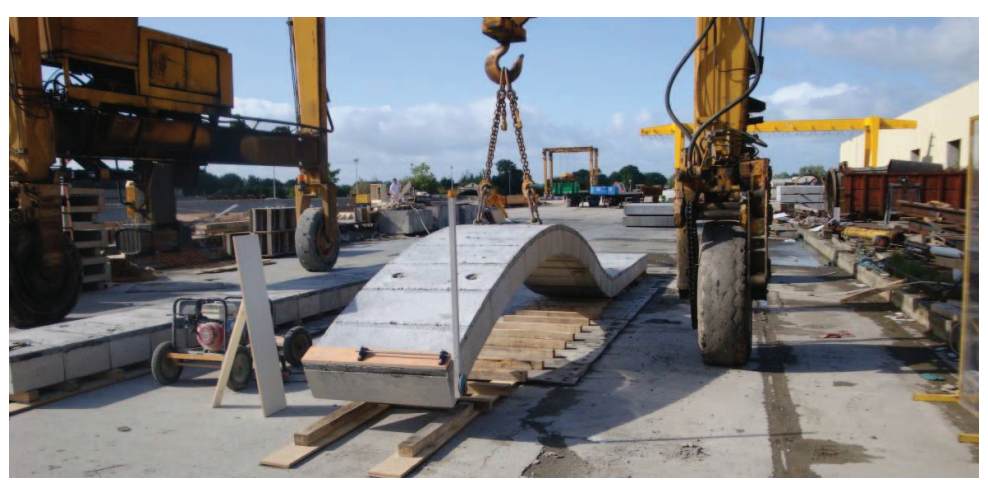

(b)

Figure 4. (a) Lifting points (used sequentially) for cantilever tests on

$10 \mathrm{~m} \times 2 \mathrm{~m}$ FlexiArch; (b) lifting FlexiArch at LP2

One of the earliest road bridges built using the system was the Tievenameena Bridge for DRD Roads Service (NI). This relatively short-span bridge had a clear span of $5 \mathrm{~m}$ and a rise of $2 \mathrm{~m}$. Each of the eight FlexiArch units required 23 precast voussoirs, which were $1 \mathrm{~m}$ wide and $200 \mathrm{~mm}$ deep, interconnected by a $40 \mathrm{~mm}$ thick in situ screed incorporating 150/15 Paragrid polymeric reinforcement. At Tievenameena the stepby-step procedure from delivery to site in flat pack form to installation on the specially tapered sill beams is shown in Figures 5(a), 5(b), 5(c) and 5(d). Subsequently precast concrete spandrel wall units were installed and backfill was added.

\begin{tabular}{lcc}
\hline Sample identity & $\begin{array}{c}\text { Tensile strength } \\
\text { for geotechnical } \\
\text { applications: kN/m }\end{array}$ & $\begin{array}{c}\text { Tensile strength } \\
\text { from beam } \\
\text { tests: kN/m }\end{array}$ \\
\hline Paragrid 150/15 & 150 & $72 \cdot 2$ \\
Paragrid 100/15 & 100 & $43 \cdot 8$
\end{tabular}

Table 1. Results of tests on polymeric reinforcement

\section{Model and full-scale tests on the FlexiArch}

Even though the FlexiArch is based on an innovative and rapid method of construction, the system has the characteristics of a conventional masonry arch including strength, stiffness and durability. However, as most practitioners are reluctant to utilise new concepts until they are well proven, it was decided that a thorough testing programme should be carried out to demonstrate its strength/stiffness and viability for a range of applications.

Model tests (third to fifth scale) were carried out in the laboratory and these allowed the ultimate capacities and stiffness to be determined. Both conventional granular backfill and lean mix concrete (used to date for arches up to $15 \mathrm{~m}$ span) were assessed for the following prototypes: $5 \mathrm{~m} \times 2 \mathrm{~m}$ rise, $8 \mathrm{~m} \times 3 \mathrm{~m}$ rise and $10 \mathrm{~m} \times 2 \mathrm{~m}$ rise. The results for granular backfill were as expected for conventional arches but lean mix concrete backfilled systems were over three times stronger.

In parallel it was decided that full-scale tests should be carried out mostly at the precasting facility in Toomebridge. These arch bridge systems were constructed by Macrete to the same rigorous standards used for all their commercial products. At 


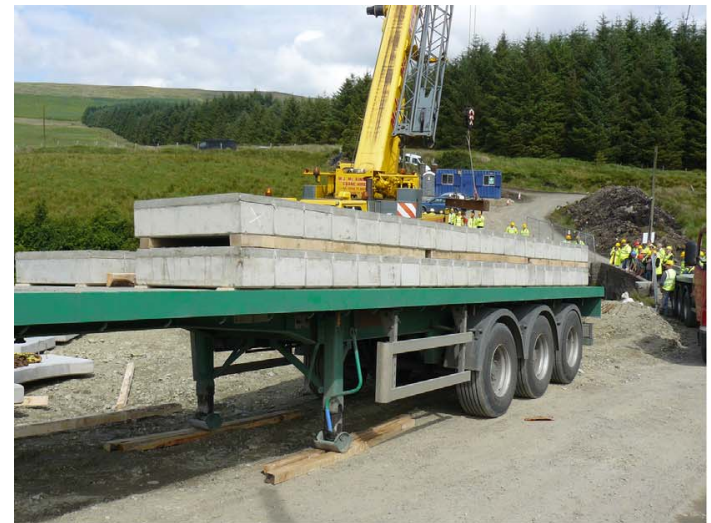

(a)

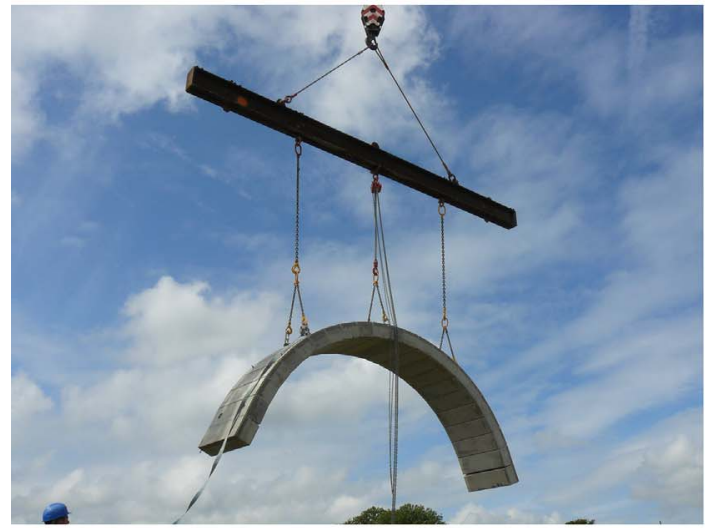

(c)

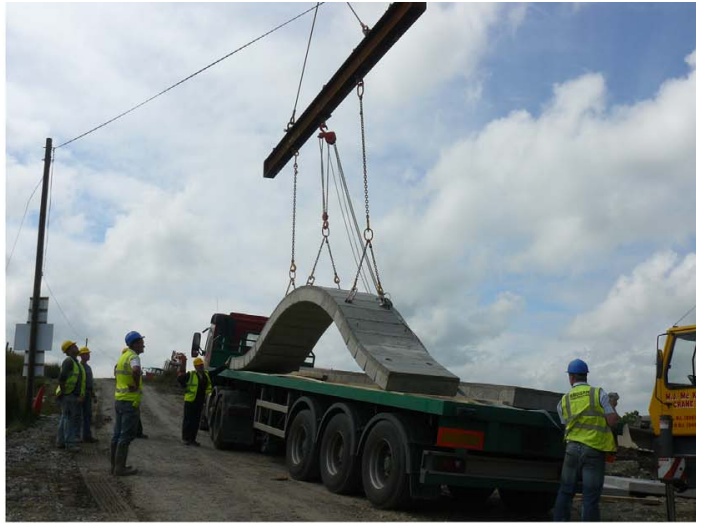

(b)

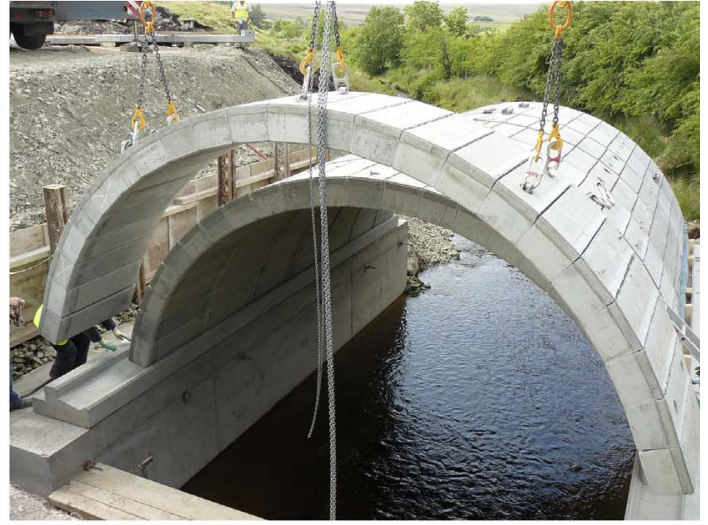

(d)

Figure 5. (a) Flat-pack arch system; (b) arch unit during lifting; (c) transfer to bridge location; (d) locating unit on precast sill beams

full scale the loading on the units during lifting and backfilling and under applied loads accurately simulated those that would occur in practice. Applied loads were mostly knife edge loads at third span or mid span.

Macrete supplied the test sites, the kentledge (heavy precast concrete units to resist the reactions produced by the hydraulic jacks) and loading beams, which allowed knife edge loads of up to $740 \mathrm{kN}$ to be applied using hydraulic jacks. The University calibrated the hydraulic jacks, installed the displacement transducers and vibrating wire strain gauges (in pairs typically at third points and mid span on the soffit) and collected/ analysed the resulting data. The following systems have been tested but only summary results are included (except for the FlexiArch with the longest span).

1. A single $1 \mathrm{~m}$ wide element of a $5 \mathrm{~m}$ span $\times 2 \mathrm{~m}$ rise arch which was backfilled with concrete. Maximum displacement $8.6 \mathrm{~mm}$ for $350 \mathrm{kN}$ axle load (but $<1 \mathrm{~mm}$ for up to $200 \mathrm{kN})$.

2. Five $1 \mathrm{~m}$ wide elements of a $5 \mathrm{~m}$ span $\times 2 \mathrm{~m}$ rise arch, which had a spandrel wall installed prior to backfilling with concrete. Maximum displacement $0.5 \mathrm{~mm}$ for $740 \mathrm{kN}$ axle load.

3. Tievenameena Bridge in Northern Ireland which was designed to meet UK Highways Agency (2004) BD91/O4 requirements and consisted of eight $1 \mathrm{~m}$ wide elements of a $5 \mathrm{~m}$ span $\times 2 \mathrm{~m}$ rise arch, spandrel walls (subsequently clad with natural stone) and concrete backfill. Subjected to three different levels of axle loadings at different locations with fibre optic sensors being used to complement the vibrating wire gauges. Maximum displacement of $0.21 \mathrm{~mm}$ for $360 \mathrm{kN}$ lorry loading. Maximum stress on soffit of voussoirs $<0.5 \mathrm{~N} / \mathrm{mm}^{2}$.

4. A single $1 \mathrm{~m}$ wide element of a $10 \mathrm{~m}$ span $\times 2 \mathrm{~m}$ rise arch which was backfilled with concrete. Maximum displacement of $1 \cdot 1 \mathrm{~mm}$ for $225 \mathrm{kN}$ axle load, maximum stress $<0.5 \mathrm{~N} / \mathrm{mm}^{2}$. Note: the equivalent full scale ultimate capacity of the parallel model test was $1440 \mathrm{kN}$.

5. A single $1 \mathrm{~m}$ wide element of a $15 \mathrm{~m}$ span $\times 3 \mathrm{~m}$ rise arch which was backfilled with lightweight concrete with low 
cement content (Figure 6). Typical load-deflection curves for third point loading and strain profiles for mid-span loading are given in Figures 7 and 8 respectively. This test representing the longest span in service at present is considered to be the most severe test of the arch bridge system which has been carried out to date.

Points that should be noted from the tests are outlined below.

In all full scale tests the maximum capacity of the loading rig was considered to be much less than the ultimate strength of the arches tested, on the basis of the results of the model tests (to failure) and the very small deformations and strains at maximum load in the full-scale tests.

- $320 \mathrm{kN}$ on $1 \mathrm{~m}$ width is equivalent to a lane loading of over $1000 \mathrm{kN}$.

Apart from tests 2 and 3, none of the arches allow the transverse distribution effects of adjacent one metre wide FlexiArch rings to be assessed. When backfilled with the lean mix concrete the system is clearly very effective. However, when conventional backfill is proposed it is recommended that either a concrete saddle (approximately the same thickness as the FlexiArch) or voussoirs with transverse male and female keys are utilised (as was anticipated in the patent (Long, 2004)). To date it has been found that contractors, on grounds of economy, prefer to use concrete backfill as this also allows the bridge to be used for traffic only a few days after the system units and spandrel walls are installed.

In the context of the load testing of arches the $15 \mathrm{~m}$ span FlexiArch is not much shorter than the longest span arch ever

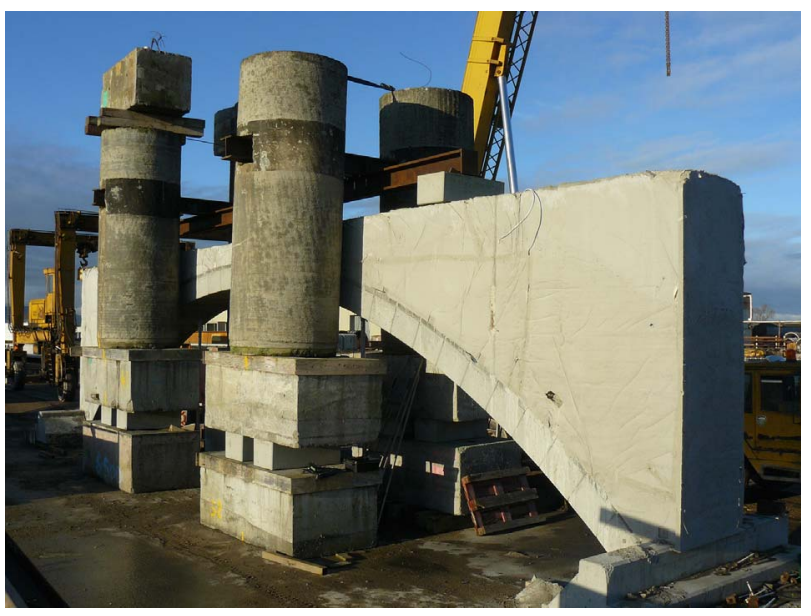

Figure 6. Testing full-scale $15 \mathrm{~m}$ span $\times 3$ rise FlexiArch tested in the UK (the Bridgemill parabolic arch at Girvan had a span of $18.29 \mathrm{~m}$ and a rise of $2.8 \mathrm{~m}$ (Hendry et al., 1985). The excellent response of this $15 \mathrm{~m}$ FlexiArch has given great confidence to users of smaller spans and acts as a showcase for potential clients for longer spans.

\section{Structural analysis of FlexiArch}

As the system functions as a conventional masonry arch, use has been made of the Archie software analysis system (Obvis Ltd, 2007), developed by Harvey, which is widely used by industry. In parallel the Cardiff spreadsheet based arch analysis software (Hughes, 2002) and the Ring software (LimitState, 2009) has been applied to selected systems.

All three gave comparable strength estimates for the system with conventional backfill but were found to give significantly lower estimated strengths than those measured in the relevant laboratory based model tests (over three times stronger). The strengths of the system with concrete backfill were not unexpectedly very much higher than those estimated by the analysis procedures based on conventional backfill (over ten times stronger).

All of these methods have also been found to give comparable predictions for horizontal and vertical reactions, which are needed for the design of the footings. Relevant design charts for reactions are being developed for a range of span/rise ratios and spans.

As far as analysis of the arch bridge system with concrete backfill is concerned, a considerable amount of developmental work has been carried out at Queen's University using a nonlinear finite-element analysis program. This approach has been found to give much improved correlation (Bourke et al., 2010).

\section{Experience gained from completed FlexiArch bridges}

Over 40 bridges have been built to date but only five will be highlighted

three cycle/foot bridges over a stream at Newtownabbey; $10 \mathrm{~m}$ span $\times 2 \mathrm{~m}$ rise $\times 2 \mathrm{~m}$ wide; spandrel walls with a concrete finish

- Tievenameena, $5 \mathrm{~m}$ span $\times 2 \mathrm{~m}$ rise $\times 8 \mathrm{~m}$ wide (Figure 5); road bridge across mountain stream; precast concrete spandrel walls clad with stone

two replacement bridges, Escot Estate, Devon, 6.5 m span $\times 2 \mathrm{~m}$ rise $\times 6 \mathrm{~m}$ wide; carrying estate road over river; precast concrete spandrel walls clad in reclaimed brickwork

Merthyr-Tydfil South Wales, $9 \mathrm{~m}$ span $\times 2.5 \mathrm{~m}$ rise $\times 3 \mathrm{~m}$ wide; bridge carrying Taff Trail (cycling/footpath) over a stream 


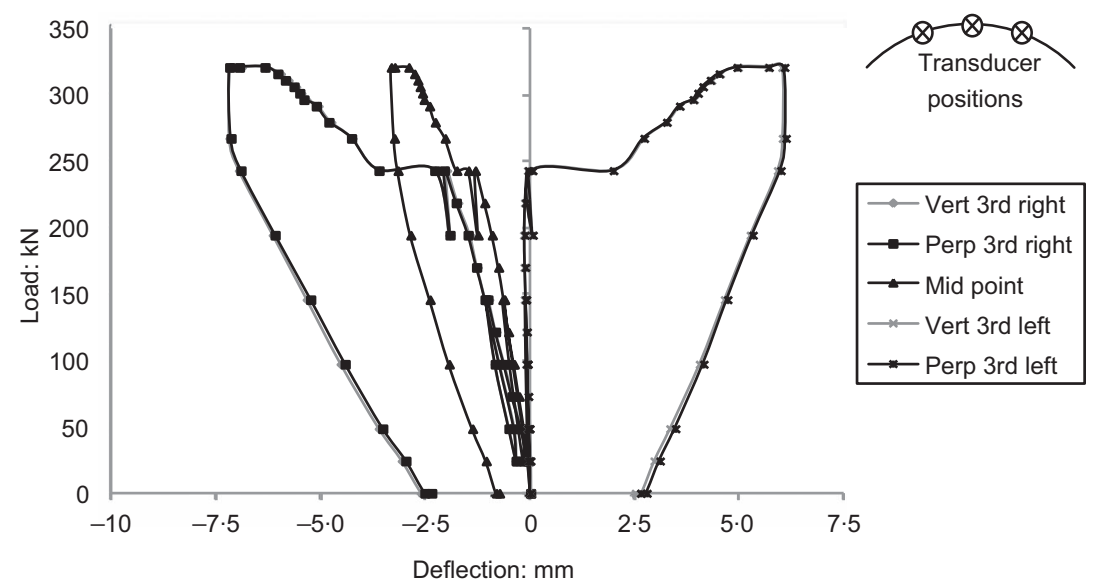

Figure 7. Load-deflection curves for knife edge load at the third point

Sheinton bridge in Shropshire, where a single span $14 \mathrm{~m} \times$ $2.8 \mathrm{~m}$ rise $\times 8 \mathrm{~m}$ wide FlexiArch was used to replace a three-span arch system destroyed by flooding in 2008 .

Further information on these and other bridges is available on the Macrete website www.macrete.com under FlexiArch.

Overall the experience gained from manufacturing, transporting and installing these bridges has been extremely beneficial to the development of the arch bridge system. The following specific aspects are highlighted

(a) improvements in the manufacture of precision moulds have resulted in the achievement of arches with more precise overall geometry

(b) lifting onto the trucks, transportation to site and installation onto precast sill beams has proven to be simple and no unforeseen problems have arisen

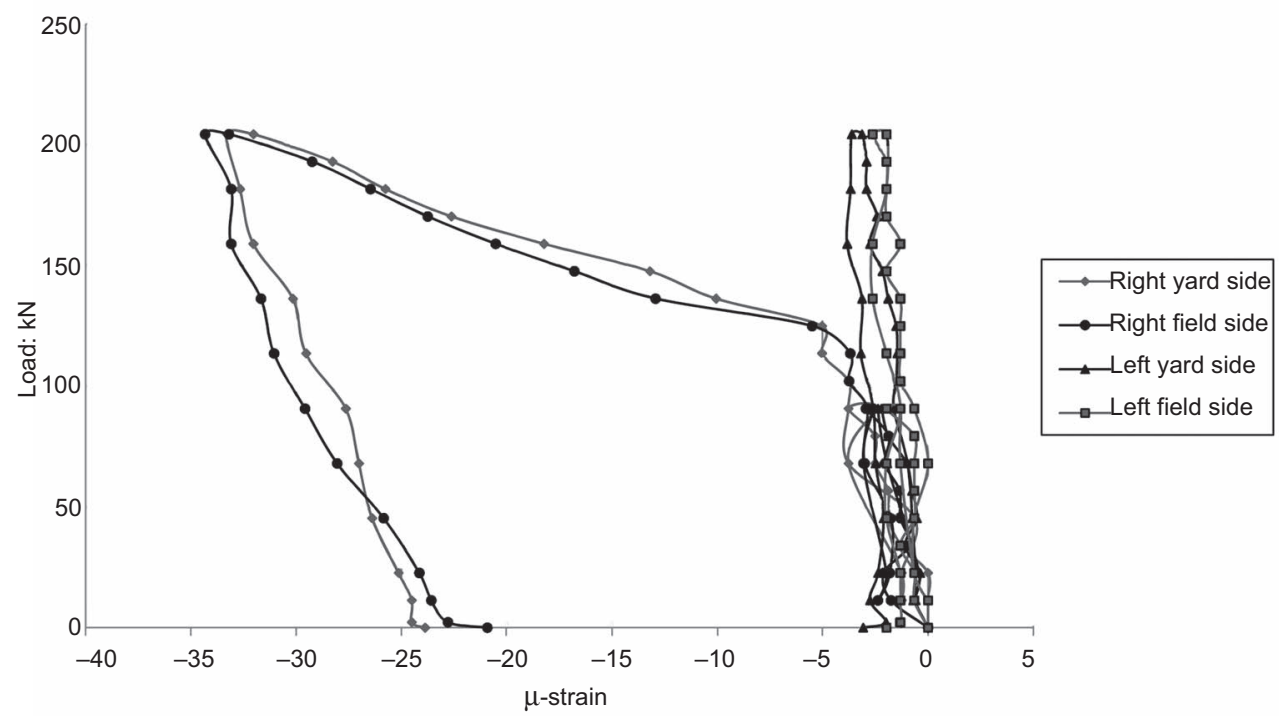

Figure 8. Load plotted against vibrating wire gauge strains for midspan loading 
(c) installation of individual FlexiArch elements can be carried out in less than 15 min and the watercourse is not disturbed (as would be the case with a box culvert) when the footings are not in water

(d) once in position the polymeric reinforcement helps to stabilise the geometry of the system during backfilling

(e) procedures for installation of the spandrel wall and resisting the pressure induced by the concrete backfill have been found to be effective

(f) once contractors, designers and clients have observed the speed and ease of installation of a FlexiArch, they have become even more favourably disposed to the system.

\section{Future technical developments}

Now that the arch bridge system has been found to perform exceptionally well for spans ranging from $4 \mathrm{~m}$ to $15 \mathrm{~m}$ with different span/rise ratios, developments, which could widen its potential market, are being considered. These are outlined below.

- Increase the maximum span - spans of at least $20 \mathrm{~m}$ are feasible and by considering more sophisticated lifting systems, spans of up to $50 \mathrm{~m}$ would appear to be viable for pedestrian bridges.

- Adapt the FlexiArch system for skew arch bridges with angles of skew up to $30^{\circ}$. Standard voussoirs can be utilised and a $10 \mathrm{~m}$ span $\times 2 \mathrm{~m}$ rise $\times 3 \mathrm{~m}$ wide system will be tested shortly.

- Alter the geometry of the arch from a segment of a circle, which has been utilised to date, to include pseudo-elliptical shapes, made up of a combination of two circular profiles. Such a system with an $8 \cdot 2 \mathrm{~m}$ span has sufficient headroom to accommodate two trains whereas the longer span $10 \mathrm{~m}$ segmental arch can only accommodate a single train. Fullscale and model tests of this system have shown that this form of a pseudo-elliptical arch could be a viable alternative to the 'Conarch' (a proprietary form of rigid frame with an arched soffit precast design by Network Rail).

Develop method statements for the use of FlexiArch units for the following.

(i) The widening of existing masonry arch bridges; this approach was successfully adopted for two bridges in Sligo, Ireland in 2010.

(ii) The replacement of multi-span arch bridges, when the abutments and piers are still sound, where the system has the benefit over conventional arch construction in that the $1 \mathrm{~m}$ wide units minimise the lateral forces on the piers during construction (Figure 9). Here it is of interest to note that relatively slender piers were used in 1771 for the five span Pont de Neuilly bridge over the Seine (Brown, 2005) by making use of the balanced thrust arch concept of Jean Rodolphe Perronet, the first director of the Ecole des Ponts and Chaussees in Paris. However, all the spans had to be

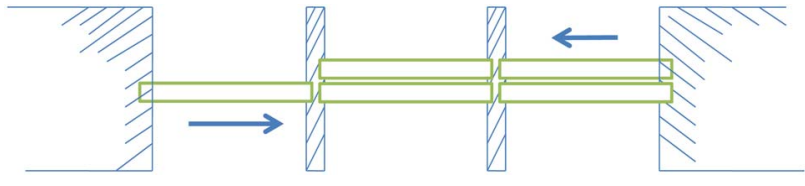

Figure 9. Installation sequence for three-span bridge

built simultaneously with expensive centring for each span. The arch bridge system therefore has great advantages in this area.

(iii) The strengthening of existing masonry arch or beam and slab bridges which are showing signs of distress. In this case FlexiArch units can be slid along new sill beams underneath the existing bridge with the space between being filled with a material such as lightweight foamed concrete.

(iv) Replacement of bridges in congested areas of cities where disruption of services is not a viable option.

\section{Concluding remarks}

In summary, the system has been found to have the following advantages over alternative systems

- precise arch geometry without the need for centring - speed of assembly/installation on site: days for FlexiArch rather than months for a traditional masonry/brick arch alternative; minimal disruption for road bridges over rail tracks

can readily be adapted to produce pseudo-elliptical or skew arches profiles to meet the requirements for specific projects/clients

modest initial costs but minimum total life cycle cost (Figure 10)

In addition the system is very sustainable as

there is no corrodible reinforcement and high-quality precast concrete is used for the major structural elements

it is cast flat, which facilitates stacking during storage and transportation and is only transformed into the desired arch geometry when it is lifted into position on site

normally water courses are not disturbed during construction.

Experiences gained from the development of the system over the past two decades have afforded an insight into innovation and have shed useful light on this important topic.

In closing it should be noted that the system facilitates the rapid construction of arches similar to those successfully used by engineers from the Roman to the Victorian eras. These aesthetically pleasing, strong, minimum maintenance bridges have withstood the test of time and have contributed greatly to 


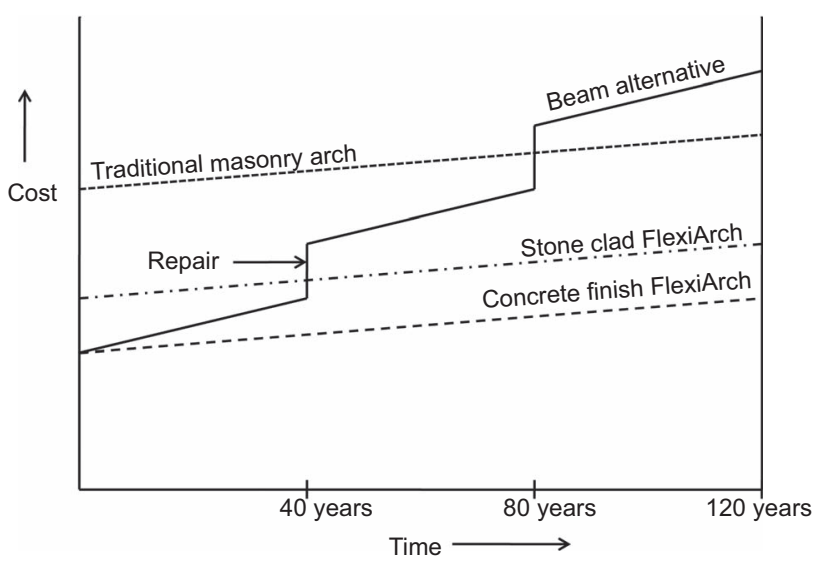

Figure 10. Initial/whole life cycle costs of alternative systems

our present infrastructure. Considerable development of the system has taken place since the original paper by Long et al. (2008), but the full potential for application to short/medium span bridges has yet to be realised.

\section{Acknowledgements}

The financial support provided by the ICE Research and Development Enabling Fund, KTP, Invest Northern Ireland, DRD Roads Service (NI) and the Leverhulme Trust is gratefully acknowledged. Input by K. McDonald, B. Rankin, S. Taylor and I. Hogg is also acknowledged.

\section{REFERENCES}

Bourke J, Taylor S, Robinson D and Long AE (2010) 'Analysis' of a flexible concrete arch. Proceedings of the Sixth International Conference on Arch Bridges, Shanghai, China, pp 133-139.
Brown DJ (2005) Bridges - Three Thousand Years of Defying Nature. Octopus Publishing Group, London, UK.

Hendry AW, Davies SR and Royles R (1985) Test on a Stone Masonry Arch at Bridgemill, Girvan. Transport and Road Research Laboratory, Berkshire, UK, Contractors Report 7, DTp.

Howells J (2002) Innovation that delivers profitable growth. James Clayton Memorial Lecture. Institution of Mechanical Engineers, London, UK. See http://www. imeche.org/knowledge/presidents-choice/ JamesClaytonLectures (accessed 04/04/2013).

Hughes TG (2002) Discussion of 'Load carrying capacity of masonry arch bridges estimated from multi-span model tests'. Proceedings of the Institution of Civil Engineers Structures and Buildings 152(4): 407-408.

LimitState (2009) LimitState: RING 2.0 software. See http:// www.limitstate.com/ring (accessed 02/07/2013).

Long AE (2004) Queen's University Belfast, 'Concrete arch and method of manufacture'. International Patent, Publication 27 May, No. WO 2004/044332A1.

Long AE, Rankin GIB, Basheer PAM, Taylor SE and Kirkpatrick J (2008) Sustainable bridge construction through innovative advances. Proceedings of the Institution of Civil Engineers Bridge Engineering 161(4): 183-188.

Obvis Ltd (2007) Archie-Msoftware. See http://www.obvis.com (accessed 04/04/2013).

Page J (1993) Masonry Arch Bridges. Transport Research Laboratory, Department of Transport, HMSO, London, UK, 118 pages.

Rankin GIB and Long AE (1987) Predicting the punching strength of conventional slab column specimens. Proceedings of Institution of Civil Engineers 1(82): 327-346. UK Highways Agency (2004) BD 91/04, Un-reinforced masonry arch bridges, Design Manual for Roads and Bridges, Vol. 1, Section 3. Department of Transport, London, UK.

\section{WHAT DO YOU THINK?}

To discuss this paper, please email up to 500 words to the editor at journals@ice.org.uk. Your contribution will be forwarded to the author(s) for a reply and, if considered appropriate by the editorial panel, will be published as discussion in a future issue of the journal.

Proceedings journals rely entirely on contributions sent in by civil engineering professionals, academics and students. Papers should be $2000-5000$ words long (briefing papers should be 1000-2000 words long), with adequate illustrations and references. You can submit your paper online via www.icevirtuallibrary.com/content/journals, where you will also find detailed author guidelines. 